\title{
Effect of level and origin of rumen degradable nitrogen on rumen microbial growth and nitrogen utilisation efficiency of animals fed maize silage at maintenance
}

\author{
Veerle FIEVEZ*, Kristof De Fauw, Kurt NotTeboom, \\ Daniël DEMEYER \\ Department of Animal Production, Faculty of Agricultural and Applied Biological Sciences, \\ Ghent University, Proefhoevestraat 10, 9090 Melle, Belgium
}

(Received 10 April 2001; accepted 9 September 2001)

\begin{abstract}
Isoenergetic maize silage diets, fed at maintenance to 24 suckling cows (Exp. 1) and to 3 (Exp. 2) or 4 (Exp. 3) rumen fistulated sheep, were compared with a urea and controlled release NPN diet (Exps. 1 and 2) and with a protein-N supplemented diet (Exp. 3). Supplementation increased blood urea concentrations ( $44.7 \pm 22.3$ vs. $97.6 \pm 23.7 \mathrm{mg}$ urea-N$\cdot \mathrm{L}^{-1}$ ) (Exp. 1) and renal urea excretion $\left(2.5 \pm 1.1\right.$ vs. $7.6 \pm 1.8 \mathrm{~g}$ urea-N.d $\left.\mathrm{d}^{-1}\right)$ (Exps. 2 and 3$)$, whereas blood allantoin concentrations $(286.7$ $\left.\pm 77.0 \mu \mathrm{mol} \cdot \mathrm{L}^{-1}\right)($ Exp. 1$)$ and renal excretion of purine derivatives $\left(357.6 \pm 90.7 \mathrm{mg}\right.$ purine $\left.-\mathrm{N} \cdot \mathrm{d}^{-1}\right)$ (Exps. 2 and 3) were not affected, indicating additional $\mathrm{N}$ supplementation did not improve rumen microbial growth. However, some deficiency of rumen degradable $\mathrm{N}$ might occur in non supplemented diets as suggested by the reduced rumen $\mathrm{NH}_{3}-\mathrm{N}$ and RNA concentrations ( $868 \pm 270$ vs. $1466 \pm 466 \mathrm{mg} \mathrm{RNA} \cdot \mathrm{kg}^{-1}$ rumen contents).
\end{abstract}

maize silage / rumen / microbial growth / maintenance / degradable nitrogen

Résumé - Effet du niveau et de la nature de l'azote dégradable sur la croissance microbienne et l'efficacité de l'utilisation d'azote dans le rumen d'animaux nourris d'ensilage de maïs à l'entretien. Des régimes isoénergétiques à base d'ensilage de maïs ont été distribués à 24 vaches (Exp. 1), et à 3 (Exp. 2) ou 4 (Exp. 3) moutons fistulés à l'entretien. Ils ont été comparés à des régimes supplémentés en urée et en une source de libération contrôlée d'urée (Exps. 1 et 2) ou en azote protéique (Exp. 3). La supplémentation augmente les concentrations sanguines d'urée (44,7 $\pm 22,3$ vs. $\left.97,6 \pm 23,7 \mathrm{mg} \mathrm{N} \cdot \mathrm{L}^{-1}\right)$ (Exp. 1) ainsi que les rejets urinaires d'urée $\left(2,5 \pm 1,1 \mathrm{vs} .7,6 \pm 1,8 \mathrm{~g} \mathrm{~N} \cdot \mathrm{j}^{-1}\right)$ (Exps. 2 et 3) tandis que la concentration sanguine d'allantoïne $\left(286,7 \pm 77,0 \mu \mathrm{mol} \cdot \mathrm{L}^{-1}\right)$ (Exp. 1) et

* Correspondence and reprints

E-mail: veerle.fievez@rug.ac.be

Presented in part at the Second Joint INRA-RRI Gastrointestinal Tract Microbiology Symposium 'Challenges for microbial digestive ecology... at the beginning of the third millennium', May, 25-26 2000, Clermont-Ferrand, France [22]. 
l'excrétion urinaire des dérivés de purines $\left(357,6 \pm 90,7 \mathrm{mg}\right.$ purine- $\left.\mathrm{N} \cdot \mathrm{j}^{-1}\right)($ Exps. 2 et 3$)$ n'ont pas été influencées, ce qui indique que la supplémentation d'azote n'augmente pas la croissance microbienne. Pourtant, $16 \mathrm{~h}$ après le repas, les régimes non supplementés montrent des concentrations réduites en ammoniac et en ARN ( $868 \pm 270$ vs. $1466 \pm 466$ mg ARN par kg de contenu ruminal) dans le rumen.

ensilage de maïs / rumen / croissance microbienne / entretien / azote dégradable

\section{ABBREVIATIONS}

BUN: blood urea nitrogen;

CRNPN: controlled release non protein nitrogen;

DVE: true protein digestible in the small intestine [56];

$\mathrm{MN}_{\mathrm{FOM}}$ : microbial nitrogen supply as estimated from fermentable OM intake [56];

$\mathrm{MN}_{\mathrm{PD}}$ : microbial nitrogen supply as estimated from urinary excretion of purine derivatives [12];

$\mathrm{MN}_{\mathrm{RPN}}$ : microbial nitrogen supply as estimated from RDN [56];

NPN: non protein nitrogen;

OEB: rumen degraded protein balance [56];

RDN: rumen degradable nitrogen;

VFA: volatile fatty acid.

\section{INTRODUCTION}

Compared to the digestible crude protein system, currently used protein evaluation systems for ruminants attempt to improve the efficiency of $\mathrm{N}$-utilisation in cattle by the incorporation of rumen $\mathrm{N}$-transactions (for examples see [54, 56, 60]). In these systems, microbial growth is predicted from the rumen energy supply, accepting a (semi) constant microbial growth rate $[2,54,56$, $60]$. However, both in vitro and in vivo experiments have revealed variations in net rumen microbial growth efficiencies (see e.g. reviews by Beever and Cotrill [2], Demeyer and Van Nevel [17], Dijkstra et al. [21]) in relation to (i) microbial recycling, mainly caused by protozoal engulfment [33], (ii) level of feed intake [10], (iii) composition of the supplemented rumen degradable nitrogen (RDN) [6, 14, 31], (iv) type and conservation of roughage [2, 26, 43] and (v) synchronisation of energy and nitrogen supply in the rumen $[30,36,43,53]$. Hence, the use of a constant microbial growth efficiency might result in an oversimplified model of in vivo events [2]. Moreover, it should be realised, that most of the systems were developed for high yielding dairy cattle and several systems (for example [56]) do not incorporate considerable possibilities for urea recycling through the rumen wall or by saliva [35].

By these currently used protein evaluation systems, maize silage is evaluated to be deficient in $\mathrm{N}$ supply for optimal rumen microbial growth (for example [54, 56, 60]). We studied the effect of correcting this RDN imbalance on the efficiency of rumen $\mathrm{N}$-utilisation in three experiments using suckling cows (Exp. 1) and fistulated sheep (Exps. 2 and 3), fed according to their maintenance requirements. Since both the quantity, nature and energy-nitrogen synchronisation rate of the rumen degradable nitrogenous compound might influence the rumen microbial yield, we compared a non supplemented maize silage diet with three types of $\mathrm{N}$ supplementation (urea and a controlled release non protein nitrogen (CRNPN) (Exps. 1 and 2) and a protein-N source (Exp. 3).

\section{MATERIALS AND METHODS}

\subsection{Animals and management}

All the experiments described were carried out in accordance with the 
recommendations of the Ethical Commission of the Ghent University (dossier of acceptance No. 98/33) and were supervised by a qualified veterinarian.

\subsubsection{Experiment 1}

Twenty-four, individually housed, suckling cows of the Belgian Blue breed (550 \pm $59 \mathrm{~kg}$ ), were studied in a Latin square design during three experimental periods, each lasting one week and preceded by 14 days of adaptation. The animals were fed twice daily, at 7 a.m. and 7 p.m.

\subsubsection{Experiments 2 and 3}

Three $(73.9 \pm 6.0 \mathrm{~kg})$ and four $(71.3 \pm$ $7.4 \mathrm{~kg}$ ) rumen fistulated mature wethers (Exps. 2 and 3, respectively), were housed in metabolic cages $(1.5 \mathrm{~m} \times 1.0 \mathrm{~m})$ under continuous lighting during the experimental period of 14 days for experiment 2 and seven days for experiment 3. During the 14 days of adaptation before each experimental period, the sheep were housed in bigger cages $(2.5 \mathrm{~m} \times 1.5 \mathrm{~m})$ adapted for individual feeding. The animals were fed twice daily at 9 a.m. and 5 p.m.

\subsection{Experimental design}

All the experiments were performed according to a Latin square design. Animals of experiments 1 and 2 were divided into three groups to study the effect of correcting the RDN imbalance of maize silage [56] by a non protein nitrogen source (NPN). In order to study the effect of a synchronised energy and nitrogen supply, urea was used in one of the NPN supplemented diets, whereas in the other a CRNPN source (Quartes N.V., Deinze, Belgium) was added. In a third experiment, the sheep were divided into two groups to study the effect of the nature of the $\mathrm{N}$ supplement. A non supplemented diet was compared with a diet supplemented with soybean meal and linseed. An overview of the experimental design is given in Table I.

Table I. Overview of the experimental design indicating the number of animals, Latin square periods, diets and samples (per animal and per treatment) and type of analyses performed.

\begin{tabular}{|c|c|c|c|c|c|c|}
\hline & \multirow[t]{2}{*}{ No. of animals } & \multirow[t]{2}{*}{ No. of periods } & \multirow[t]{2}{*}{ No. of diets } & \multicolumn{3}{|c|}{ Samples } \\
\hline & & & & Urine & Blood & Rumen \\
\hline Exp. 1 & 24 & 3 & 3 & - & $3^{\mathrm{a}} \times 2^{\mathrm{b}}$ & - \\
\hline Exp. 2 & 3 & 3 & 3 & 4 & - & $4^{\mathrm{a}} \times 12^{\mathrm{b}}$ \\
\hline \multirow[t]{3}{*}{ Exp. 3} & 4 & 2 & 2 & 3 & - & $3^{\mathrm{a}} \times 12^{\mathrm{b}}$ \\
\hline & & & & \multicolumn{3}{|c|}{ Analyses } \\
\hline & & & & $\begin{array}{l}\text { Allantoin } \\
\text { Urea }\end{array}$ & $\begin{array}{l}\text { Allantoin } \\
\text { Urea }\end{array}$ & $\begin{array}{c}\mathrm{RNA}^{\mathrm{c}} \\
\mathrm{NH}_{3} \\
\mathrm{VFA}\end{array}$ \\
\hline
\end{tabular}

${ }^{a}$ Number of sampling days.

${ }^{b}$ Number of samples at different times after feeding within the same sampling day.

${ }^{c}$ RNA was analysed in duplicate on samples taken at one of the 12 sampling times ( $16 \mathrm{~h}$ after feeding). 


\subsection{Composition of the experimental diets}

\subsubsection{Maize silage}

The maize silage was made from maize harvested in September of the former year. Its chemical characteristics are shown in Table II. From OEB-values (rumen degraded protein balance) [56], the utilised maize silage could be calculated to show a deficiency of 4.0 to $4.8 \mathrm{~g} \mathrm{~N} \cdot \mathrm{kg}^{-1} \mathrm{DM}$ for optimal rumen microbial growth. In experiments 2 and 3, sufficient maize silage for the whole experiment was stored, until required, under vacuum at $-15^{\circ} \mathrm{C}$ in separate plastic bags, containing enough silage for one feeding portion.

\subsubsection{CRNPN}

The liquid CRNPN source used in experiments 1 and 2 consisted of urea chemically bounded to sugar cane molasses (46\%, Quartes N.V., Deinze, Belgium, see Tab. III).

\subsubsection{Protein- $N$}

The protein- $\mathrm{N}$ source used in experiment 3 was a mixture of soybean meal and linseed (after mechanical extraction of the oil, see Tab. III).

The diets were fed according to the animals' maintenance requirements for energy (VEM) [15] and were always isoenergetic (Tab. IV). In order to obtain isoenergetic diets, molasses (Tab. III) was added to the blank and urea supplemented diets in experiments 1 and 2. The feed offered was completely consumed on all occasions. For the supplemented diets, the NPN or protein-N supplementation was calculated to provide $33.8 \%, 26.8 \%$ and $15.6 \%$ of the rumen degradable $\mathrm{N}(\mathrm{RDN})$ in experiments 1,2 and 3 respectively [15].

Table II. Chemical characteristics of maize silage used in the three experiments.

\begin{tabular}{lcccccccc}
\hline & $\begin{array}{c}\mathrm{DM}^{1} \\
(\%)\end{array}$ & $\mathrm{OM}^{1}$ & $\mathrm{CP}^{1}$ & $\mathrm{CFi}^{1}$ & $\begin{array}{c}\mathrm{CF}^{1} \\
\mathrm{~g} \cdot \mathrm{kg}^{-1} \mathrm{DM}\end{array}$ & $\mathrm{VEM}^{1}$ & $\mathrm{DVE}^{1}$ & $\mathrm{OEB}^{1}$ \\
\hline Exp. 1 & 29.6 & 959.5 & 87.8 & 172.3 & $-^{2}$ & 912 & 46 & -30 \\
Exp. 2 & 30.1 & 948.0 & 86.0 & 185.0 & 35.0 & 917 & 49 & -25 \\
Exp. 3 & 31.0 & 952 & 85.6 & 187.0 & $-^{2}$ & 909 & 47 & -27 \\
\hline
\end{tabular}

${ }^{1} \mathrm{DM}$, dry matter; OM, organic matter; $\mathrm{CP}$, crude protein; $\mathrm{CFi}$, crude fibre; $\mathrm{CF}$, crude fat; VEM, feed unit milk $(1000 \mathrm{VEM}=6.9 \mathrm{MJ})$ [15]; DVE, true protein digested in the small intestine [56]; OEB, degradable protein balance [56].

${ }^{2}$ Not determined.

Table III. Chemical characteristics of CRNPN source (controlled release non protein nitrogen, Quartes N.V., Deinze, Belgium), soybean meal (SM), linseed and molasses.

\begin{tabular}{lcccccccc}
\hline & $\begin{array}{c}\mathrm{DM}^{1} \\
(\%)\end{array}$ & $\mathrm{OM}^{1}$ & $\mathrm{CP}^{1}$ & $\mathrm{CFi}^{1}$ & $\begin{array}{c}\mathrm{CF}^{1} \\
\mathrm{~g} \cdot \mathrm{kg}^{-1} \mathrm{DM}\end{array}$ & $\mathrm{VEM}^{1}$ & $\mathrm{DVE}^{1}$ & $\mathrm{OEB}^{1}$ \\
\hline CRNPN & 62.5 & 840.0 & 640.0 & $-^{2}$ & $-^{2}$ & 800 & 112 & 480 \\
SM & 87.7 & 926.5 & 417.6 & 69.0 & 21.1 & 1137 & 259 & 181 \\
Linseed & 89.9 & 937.7 & 303.7 & 113.5 & 85.7 & 1091 & 170 & 111 \\
Molasses & 74.5 & $-^{2}$ & $-^{2}$ & $-^{2}$ & $-^{2}$ & 858 & 50 & -43 \\
\hline
\end{tabular}

\footnotetext{
${ }^{1}$ See Table II.
}

${ }^{2}$ Not determined. 
Table IV. Average diet composition (kg DM/day/animal).

\begin{tabular}{|c|c|c|c|c|c|c|}
\hline & Maize silage & Molasses & Urea & $\mathrm{CRNPN}^{1}$ & Soybean meal & Linseed meal \\
\hline \multicolumn{7}{|l|}{ Exp. 1} \\
\hline Blank & 8.1 & 0.19 & - & - & - & - \\
\hline Urea & 8.1 & 0.19 & 0.089 & - & - & - \\
\hline CRNPN & 8.1 & - & - & 0.5 & - & - \\
\hline \multicolumn{7}{|l|}{ Exp. 2} \\
\hline Blank & 0.81 & 0.016 & - & - & - & - \\
\hline Urea & 0.81 & 0.016 & 0.007 & - & - & - \\
\hline CRNPN & 0.81 & - & - & 0.042 & - & - \\
\hline \multicolumn{7}{|l|}{ Exp. 3} \\
\hline Blank & 0.81 & - & - & - & - & - \\
\hline Protein-N & 0.66 & - & - & - & 0.049 & 0.074 \\
\hline
\end{tabular}

${ }^{1}$ CRNPN, controlled release non protein nitrogen (Quartes N.V., Deinze, Belgium).

\subsection{Sampling}

\subsubsection{Experiment 1}

\section{Blood plasma samples for urea} and allantoin determination

Each experimental period provided six blood samples per animal, taken on three different sampling days at 3 and $9 \mathrm{~h}$ after feeding (Tab. I). These sampling times were chosen since the blood peak urea concentration has been shown to occur $3 \mathrm{~h}$ after feeding, whereas the blood urea (BUN) concentration $9 \mathrm{~h}$ after feeding corresponds with the basal BUN level [27]. Samples were collected in heparinised tubes from the arteria or vena caudalis mediana and centrifuged immediately at $3000 \mathrm{~g}$ at $4{ }^{\circ} \mathrm{C}$. Plasma was divided into two portions and preserved at $-20{ }^{\circ} \mathrm{C}$ till analysis of urea or allantoin.

\subsubsection{Experiments 2 and 3}

\subsubsection{Total urine collection for urea} and purine derivative determination

In experiments 2 and 3, total urine collection $(24 \mathrm{~h})$ was carried out during four and three days respectively. Urine was collected using a collection device, fitted closely under the wether in order to prevent faecal contamination of the urine samples. The collection device was connected by a tube to a reservoir in which urine was preserved by adding sulphuric acid $4 \mathrm{M}(\mathrm{pH}<3)$ stepwise with increasing urine volume. Each $24 \mathrm{~h}$ urine collection was diluted to 7 litres (to prevent precipitation of uric acid during storage [10]). A representative subsample was taken and stored at $-20{ }^{\circ} \mathrm{C}$ until analysis for purine derivatives and urea.

\subsubsection{Rumen samples for $\mathrm{NH}_{3}$ and VFA determination}

During three experimental days, rumen contents were sampled at $0.5,1,2,3,4,5,6$, $7,8,11,13.5$ and $16 \mathrm{~h}$ after feeding between 5 p.m. and 9 a.m., to follow pH (PHM Standard $\mathrm{pH}$ meter, Radiometer, Copenhagen, Denmark) and ammonia $\left(\mathrm{NH}_{3}\right)$ and volatile fatty acid (VFA) concentrations. After $\mathrm{pH}$ measurement, rumen samples were acidified by $2 \%$ (final concentration) addition of phosphoric/formic (10/1, v/v) acid, centrifuged $(10 \mathrm{~min}$ at $22000 \mathrm{~g}$ ), filtered and the filtrate stored at $4{ }^{\circ} \mathrm{C}$ till further analyses. 


\subsubsection{Rumen samples for RNA determination}

To evaluate whether the nutritional environment, in particular $\mathrm{N}$ supply, becomes limiting with time after feeding, microbial biomass was estimated $16 \mathrm{~h}$ after feeding, using rumen RNA concentration as an indicator of rumen microbial biomass. Indeed, since early studies showed nucleic acids in feed to be rapidly degraded [40], rumen RNA was assumed to be mainly from microbial origin $16 \mathrm{~h}$ after feeding. Hence, during 4 , respectively 3 days of the experimental periods of experiments 2 and 3,350 mL of whole (liquid + solid phase) rumen contents was sampled just before the morning feeding, from which two representative subsamples of $10 \mathrm{~g}$ were removed for RNA analysis.

\subsection{Analyses}

\subsubsection{HPLC analysis of purine derivatives}

\subsubsection{Instrumentation}

A single pumping system with two pumping heads (HPLC controller 2152, solvent conditioner 2156, HPLC pump 2150, LKB, Bromma, Sweden), equipped with an automatic injector, injecting $20 \mu \mathrm{L}$ sample (Sampling Injector 234, Gilson, Analis, Ghent, Belgium) was used. A precolumn ( $\mu$ bondabpack $\mathrm{C}_{18}$, Waters, Brussels, Belgium) was used to protect the Nucleosil column (100 A, $5 \mu \mathrm{m} \mathrm{C}_{18} 4 \times 250 \mathrm{~mm}$, Machery Nagel, Altech, Lokeren, Belgium).

\subsubsection{Buffer solutions}

An initial stock solution of $0.1 \mathrm{M}$ $\mathrm{KH}_{2} \mathrm{PO}_{4}$ was prepared and kept at $4{ }^{\circ} \mathrm{C}$. Working buffers were prepared daily. Buffer A was prepared by diluting $100 \mathrm{~mL}$ stock solution to $1 \mathrm{~L}$ with milli-Q water (Millipore, Brussels, Belgium), to which one ampoule of PIC reagent (PIC ${ }^{\circledR}$ B-8 Low UV-Regent, Waters, Brussels, Belgium) was added. Afterwards, the $\mathrm{pH}$ was adjusted to
4.0 with phosphoric acid and the buffer was filtered through a $0.45 \mu \mathrm{m}$ filter (Millipore, Brussels, Belgium). For allantoin analysis in blood plasma samples (Exp. 1), methanol/ water (1:1) was used as buffer B. For the urine samples (Exps. 2 and 3), buffer B was prepared by diluting $100 \mathrm{~mL}$ of the stock solution to $800 \mathrm{~mL}$ with milli-Q water, the $\mathrm{pH}$ was adjusted to 4.0 and $200 \mathrm{~mL}$ acetonitrile was added. Before use, buffers were always stirred for $30 \mathrm{~min}$ at room temperature.

\subsubsection{Chromatographic conditions}

System 1 was adopted for the determination of allantoin in blood plasma, system 2 for the complete analysis of purine metabolites in the urine samples. The buffer solutions in both systems were run at $1 \mathrm{~mL} \cdot \mathrm{min}^{-1}$ and the effluent was monitored at $205 \mathrm{~nm}$. In system 1, after buffer B was kept at $0 \%$ for $1 \mathrm{~min}$, a linear gradient from 0 to $40 \%$ buffer $\mathrm{B}$ was run during the following 29 minutes. The latter amount of buffer B was held for 5 minutes, thereafter the column was reequilibrated for 20 minutes. System 2, was run with the following sequential gradient steps for buffer B: $0 \%$ for $2 \mathrm{~min}$, a linear gradient till $30 \%$ for the following $13 \mathrm{~min}$ and a linear gradient till $100 \%$ for 15 minutes, then the column was re-equilibrated for 20 minutes.

\subsubsection{Pre-treatment of samples}

Allopurinol was added as the internal standard to both blood plasma and diluted urine samples. Afterwards, blood plasma samples were pre-treated as described by Balcells et al. [1]. Finally, both the treated blood plasma samples and the diluted urine samples were filtered through a $0.45 \mu \mathrm{m}$ filter (Altech, Laarne, Belgium) just before HPLC-analysis. Blood samples were analysed for allantoin, whereas in urine samples hypoxantine and uric acid were determined besides allantoin. Urinary xantine concentrations were negligible. All purine standards (allantoin, hypoxantine, xantine and 
uric acid) as well as allopurinol were purchased from Sigma (Bornem, Belgium).

\subsubsection{Plasma urea concentrations}

They were determined colorimetrically after transformation of urea to $\mathrm{NH}_{3}$ as described by Diez et al. [19].

\subsubsection{Urea in the urine}

Urea in the urine samples were analysed according to the method developed by Dierick [18] in which urea was first transformed to $\mathrm{NH}_{3}$. Afterwards, $\mathrm{NH}_{3}$ was determined using the microdiffusion method of Conway [13].

\subsection{4. $\mathrm{NH}_{3}$ and $\mathrm{VFA}$ concentrations}

$\mathrm{NH}_{3}$ and VFA concentrations in the acidified rumen samples were analysed respectively using the microdiffusion method of Conway [13] and by gas-liquid chromatography (GC 14, Shimadzu, 's Hertogenbosch, the Netherlands) as described by Marty and Demeyer [38].

\subsubsection{Analysis of rumen RNA concentrations}

They are based on the orcinol method as described by Herbert et al. [29].

\subsection{In vitro incubations}

During the second experiment, 6 in vitro incubations were carried out as described by Mbanzamihigo et al. [39], using $10 \mathrm{~mL}$ rumen contents of the studied sheep, $40 \mathrm{~mL}$ Burroughs buffer [4], $1.0 \mathrm{~g}$ (DM) grounded maize silage and $67.25 \mathrm{mg} \mathrm{N}$ from urea or the CRNPN source. Supplemented N from both NPN sources was highly in excess of $\mathrm{N}$ needed for microbial growth. VFA production and $\mathrm{NH}_{3}$ accumulation were determined after $0,1,2,4$ and $6 \mathrm{~h}$ of incubation as described for the determination of VFA and $\mathrm{NH}_{3}$ concentration in vivo.

\subsection{Calculations}

2.7.1. $M N_{P D}$ based on urinary excretion
of $P D$ of PD

Conversion of total daily renal excretion of purine derivatives $\left(\mathrm{PD}_{\mathrm{e}}\right.$ ) to daily duodenal flux of microbial $\mathrm{N}\left(\mathrm{MN}_{\mathrm{PD}}\right)$ was calculated based on the equation of Chen and Gomes [12]:

$\mathrm{MN}_{\mathrm{PD}}=\left(\mathrm{PD}_{\mathrm{a}} \times 70\right) /(0.116 \times 0.83 \times 1000)$

with $70, \mathrm{~N}$ content of purines $(70 \mathrm{mg}$ $\left.\mathrm{N} \cdot \mathrm{mmol}^{-1}\right) ; 0.116$, ratio of purine- $\mathrm{N}$ to total $\mathrm{N}$ in mixed rumen microbes; 0.83 , digestibility of microbial purines; $\mathrm{PD}_{\mathrm{a}}$, microbial purines absorbed from the small intestine $\left(\mathrm{mmol} \cdot \mathrm{d}^{-1}\right)$ calculated as:

$\mathrm{PD}_{\mathrm{a}}=0.84 \times \mathrm{PD}_{\mathrm{e}}+\left(0.15 \times \mathrm{W}^{0.75} \times \mathrm{e}^{\left.-0.25 \times \mathrm{PD}_{\mathrm{e}}\right)}\right.$

with $\mathrm{PD}_{\mathrm{e}}$, microbial purines excreted in the urine $\left(\mathrm{mmol} \cdot \mathrm{d}^{-1}\right) ; \mathrm{W}^{0.75}$, metabolic body weight of the animal $(\mathrm{kg})$; the slope 0.84 represents the recovery of absorbed purines in the urine; the component within brackets represents the endogenous contribution of purine derivatives to total excretion after correction for the utilisation of microbial purines by the animal.

\subsubsection{MN $N_{\text {FOM }}$ based on intake of FOM}

In the Belgian and Dutch protein evaluation system microbial $\mathrm{N}$ supply is calculated from the intake of fermentable $\mathrm{OM}$ $\left(\mathrm{FOM}, \mathrm{kg} \cdot \mathrm{d}^{-1}\right)$ [56] as:

$$
\mathrm{MN}_{\mathrm{FOM}}=150 \times \mathrm{FOM} / 6.25 .
$$

\subsection{3. $M N_{R D N}$ based on intake of $R D N$}

Based on the intake of RDN, microbial N supply can be calculated as:

$\mathrm{MN}_{\mathrm{RPN}}=\frac{[\mathrm{CP} \times(1-1.11 \times \% \mathrm{BRE} / 100)]}{6.25}$

with \%BRE, the fraction of rumen undegraded feed CP in total feed CP [56]. 


\subsection{Statistics}

A SPSS software for Windows (release 9.0, SPSS, Inc., USA) was used.

\subsubsection{Experiment 1}

Since blood concentrations of urea and allantoin at $9 \mathrm{~h}$ were not independent of values observed $3 \mathrm{~h}$ after feeding, a split plot analysis for repeated measures was used to evaluate the effect of $\mathrm{N}$ supplementation, animal, Latin square period and sampling time. The effect of sampling time was evaluated from the 'within-subject-effect'. $\mathrm{N}$ supplementation, period and animal were introduced as 'between-subject-factors' and their effects evaluated from the 'betweensubject-effects'. A post-hoc duncan test was performed for $\mathrm{N}$ supplementation after splitting the data file per sampling time.

\subsubsection{Experiments 2 and 3}

Renal excretions of purine derivatives, urinary urea excretions and rumen RNA concentrations were compared using analysis of variance (ANOVA), general factorial design, with animal, period and supplementation (non supplemented vs. urea vs. CRNPN, Exp. 2, and non supplemented vs. protein-N, Exp. 3) as main factors. In experiment 2, a post-hoc duncan test allowed to distinguish the effect of the three different $\mathrm{N}$ supplementation treatments. To compare rumen $\mathrm{NH}_{3}-\mathrm{N}$ and VFA concentrations with time after feeding, split plot analysis for repeated measures was performed as for experiment 1. Again, the effect of sampling time was evaluated from the 'within-subject-effect' and the animal, period and $\mathrm{N}$ supplementation effect from the 'betweensubject-effects'. A post-hoc duncan test was performed to evaluate the effect of $\mathrm{N}$ supplementation in experiment 2.

\subsubsection{In vitro incubations}

$\mathrm{NH}_{3}-\mathrm{N}$ accumulation from urea and CRNPN source were compared using split plot analysis for repeated measures. The effect of incubation time was tested as the 'within-subject-effect' and urea and CRNPN were compared based on 'between-subjecteffects'.

\section{RESULTS}

\subsection{In vitro incubations}

From total mean VFA production (2605 \pm $439 \mu$ mol per incubation) and average relative individual VFA productions of acetate, propionate and butyrate $(54.5 \pm 2.3 \%, 22.6 \pm$ $6.5 \%$ and $19.2 \pm 6.2 \%$, respectively), FOM was calculated to represent $243.6 \pm 40.4 \mathrm{mg}$ per incubation [16]. Since in vitro incubation conditions are not supportive of protozoal growth metabolism, net microbial incorporation of 60 to $70 \mathrm{mg} \mathrm{N} \cdot \mathrm{kg}^{-1} \mathrm{FOM}$ could be assumed [34]. Hence, bacterial growth can be assumed to result in a maximal uptake of $\mathrm{NH}_{3}-\mathrm{N}$ of 14.6 to $17.1 \mathrm{mg}$, indicating the addition of $67.25 \mathrm{mg} \mathrm{N}$ from urea or CRNPN is clearly in excess compared to the possible uptake by rumen bacteria. After $6 \mathrm{~h}$ of incubation, an accumulation of about $16 \mathrm{mg}$ $\mathrm{NH}_{3}-\mathrm{N}$ could be observed for both NPN sources (Fig. 1). Surprisingly, after $6 \mathrm{~h}$ of incubation still $31.1 \pm 1.9 \mathrm{mg} \mathrm{N}$ was recovered as urea (data not shown).

\subsection{Rumen $\mathrm{N}$ and energy release}

In vitro $\mathrm{NH}_{3}-\mathrm{N}$ accumulation (Fig. 1), suggests only a minor and non significant tendency $(p=0.32)$ for a slower $\mathrm{N}$ release in the rumen from the CRNPN source. This has been confirmed during the in vivo trials, since neither BUN concentrations (Tab. V) nor rumen $\mathrm{NH}_{3}-\mathrm{N}$ patterns (Fig. 2) differed significantly between the urea and the CRNPN supplemented diet. Peak rumen $\mathrm{NH}_{3}-\mathrm{N}$ concentrations were reached between 0.5 and 2 hours after feeding for all diets (Fig. 2). However, compared to the NPN supplemented diets (Exp. 2), supplementation of a mixture of soybean meal and 
linseed (Exp. 3) induced lower rumen peak $\mathrm{NH}_{3}-\mathrm{N}$ concentrations and higher basal concentrations (Fig. 2). Rumen $\mathrm{NH}_{3}-\mathrm{N}$ (Exps. 2 and 3, Fig. 2) and BUN (Exp. 1, Tab. V) concentrations decreased significantly with time after feeding $(p<0.01)$. However, for none of the diets in experiments 2 and 3 , mean rumen $\mathrm{NH}_{3}-\mathrm{N}$ concentrations decreased significantly below $3.5 \mathrm{mM}$.
The relative contribution of iso-acids (sum of iso-butyric and iso-valeric acid) to the total rumen VFA concentration did not differ between the non supplemented and the NPN supplemented diets (data not shown, Exp. 2), but increased slightly when a protein-N source was supplemented (2.26 \pm 0.63 vs. $2.64 \pm 0.77 \mathrm{mmol} \cdot \mathrm{mol}^{-1}$ total VFA, $p<0.05, n=144$, Exp. 3). No significant

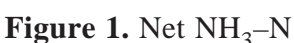
accumulation during 1 , 2, 4 and $6 \mathrm{~h}$ of in vitro incubation with rumen contents, Burroughs buffer, maize silage and $67.25 \mathrm{mg} \mathrm{N}$ from urea (full line and symbols) or CRNPN (Quartes N.V., Deinze, Belgium, dotted line), $n=6$.

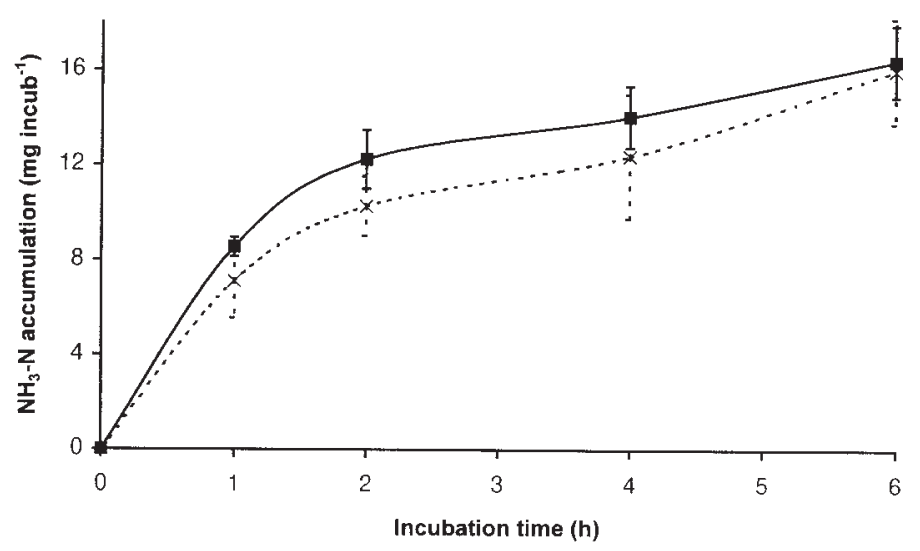

Table V. Blood plasma urea $\left(\mathrm{mg} \mathrm{N} \cdot \mathrm{L}^{-1}\right)$ and allantoin $\left(\mu \mathrm{mol} \cdot \mathrm{L}^{-1}\right)$ concentrations 3 and $9 \mathrm{~h}$ after feeding (Exp. 1, mean, $n=72$ ).

\begin{tabular}{|c|c|c|c|c|c|c|}
\hline \multirow[t]{2}{*}{ Time after feeding } & \multirow[t]{2}{*}{ Blank } & \multirow[t]{2}{*}{ Urea } & \multirow[t]{2}{*}{$\mathrm{CRNPN}^{1}$} & \multirow[t]{2}{*}{ S.E.M. ${ }^{2}$} & \multicolumn{2}{|c|}{ Statistics $^{3}$} \\
\hline & & & & & Animal & N suppl. \\
\hline \multicolumn{7}{|l|}{ Urea } \\
\hline $3 \mathrm{~h}$ & $47.2^{\mathrm{a}}$ & $108.6^{\mathrm{b}}$ & $106.4^{b}$ & 2.3 & $* * *$ & $* * *$ \\
\hline $9 \mathrm{~h}$ & $42.2^{\mathrm{a}}$ & $94.7^{\mathrm{b}}$ & $80.8^{\mathrm{c}}$ & 2.5 & & \\
\hline \multicolumn{7}{|l|}{ Statistics $^{3}$} \\
\hline Sampling time & 0.175 & $* * *$ & $* * *$ & & & \\
\hline \multicolumn{7}{|l|}{ Allantoin } \\
\hline $3 \mathrm{~h}$ & 303.1 & 287.9 & 275.5 & 6.1 & $* *$ & 0.224 \\
\hline $9 \mathrm{~h}$ & 275.7 & 271.3 & 283.8 & 7.3 & & \\
\hline \multicolumn{7}{|l|}{ Statistics $^{3}$} \\
\hline Sampling time & 0.133 & 0.356 & 0.690 & & & \\
\hline
\end{tabular}

${ }^{1}$ CRNPN, controlled release non protein nitrogen (Quartes N.V., Deinze, Belgium).

${ }^{2}$ Standard error of mean.

$3 * * * p<0.001 ; * * p<0.01 ; * p<0.05$; when not significant, $p$-value is shown.

a,b,c Different letters within same row indicate significant differences between different $\mathrm{N}$ supplements $(p<0.05)$. 

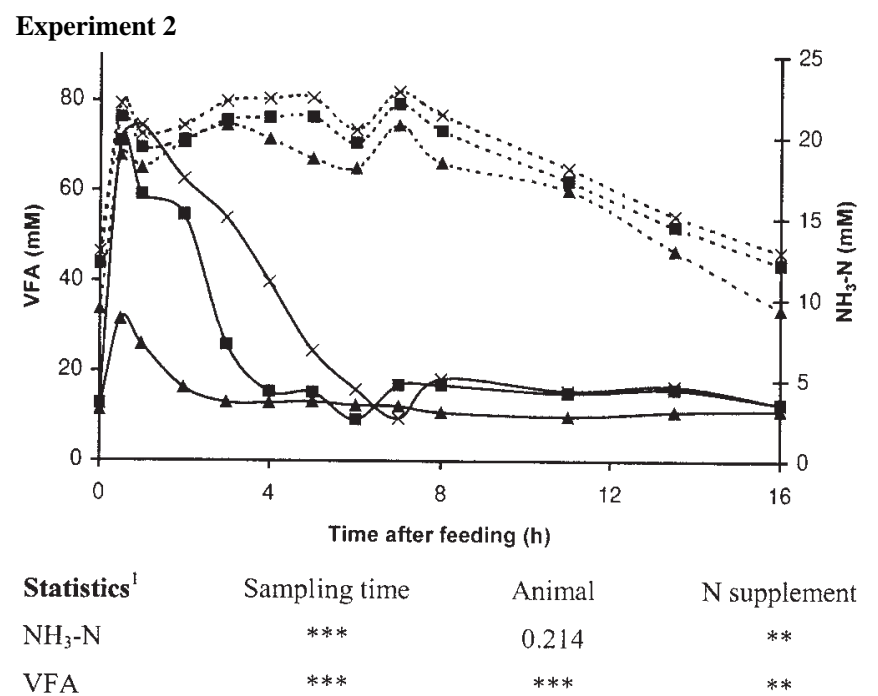

Experiment 3

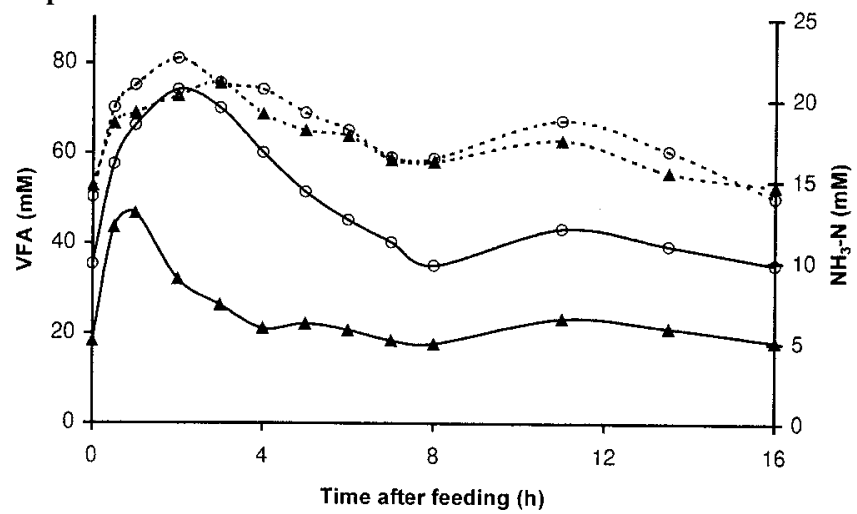

$\begin{array}{lccc}\text { Statistics }^{1} & \text { Sampling time } & \text { Animal } & \text { N supplement } \\ \mathrm{NH}_{3}-\mathrm{N} & * * * & 0.183 & * * * \\ \text { VFA } & * * * & 0.119 & 0.636\end{array}$

Figure 2. Rumen VFA(dotted lines) and $\mathrm{NH}_{3}-\mathrm{N}$ (full lines) pattern with time after feeding for non supplemented maize silage diets $(\boldsymbol{\Lambda}$, Exps. 2 and 3$)$ and urea (घ, Exp. 2), CRNPN (Quartes N.V., Deinze, Belgium) (×, Exp. 2) and protein-N (O, Exp. 3) supplemented maize silage diets $(n=12)$. In order to assure readability of the figure standard deviations were VFA not shown.

$1 * * * p<0.001 ; * * p<0.01 ; * p<0.05$; when not significant, $p$-value is shown.

differences were observed between the non supplemented and $\mathrm{N}$ supplemented diets in experiment 3 for total VFA (Fig. 2) and in both experiments 2 and 3 for individual (data not shown) VFA concentrations. In experiment 2, mean total VFA concentrations of the non supplemented diet $\left(64.7 \mathrm{mmol} \cdot \mathrm{L}^{-1}\right)$ was slightly lower than for the NPN supplemented diets $\left(71.8 \mathrm{mmol} \cdot \mathrm{L}^{-1}\right)$.

\subsection{Rumen microbial growth}

During the first experiment, no significant change of the blood allantoin concentration could be observed with either time after feeding or $\mathrm{N}$ supplementation (Tab. V). Also the trials with fistulated sheep (Exps. 2 and 3 ) revealed that $\mathrm{N}$ supplementation did not increase rumen microbial growth as 
estimated from daily renal excretion of purine derivatives (Tab. VI). However, rumen RNA concentrations, $16 \mathrm{~h}$ after feeding, were significantly lower when the maize silage diet was not supplemented (Tab. VI).

\subsection{Renal urea-N excretion}

Irrespective of its origin, compared to the non supplemented diet (blank), dietary $\mathrm{N}$ supplementation induced an increase in urinary urea-N excretion (Tab. VI).

\section{DISCUSSION}

\subsection{Rumen $\mathrm{N}$ availability}

BUN concentrations can be assumed to give an indication of the rumen $\mathrm{N}$ availability [5, 27, 35] of the suckling cows studied in experiment 1 . BUN concentrations of the non supplemented diet were comparable with those reported by Oltner and Wiktorsson [44] and Gonda and Lindberg [25], using similar diets with regards to $\mathrm{N}$ supply and were significantly lower than during feeding of the supplemented diets. Compared to the urea supplemented diet, the CRNPN supplementation induced similar peak BUN ( $3 \mathrm{~h}$ after feeding) and decreased basal BUN ( $9 \mathrm{~h}$ after feeding) concentrations, suggesting no slow release effect of the CRNPN source. This has been confirmed in vitro (Fig. 1) and in vivo with rumen fistulated sheep (Exp. 2, Fig. 2). As $\mathrm{NH}_{3}-\mathrm{N}$ concentrations for both the non and NPN supplemented diets (Exp. 2) are close to $3.5 \mathrm{mM}$ from about $8 \mathrm{~h}$ after feeding (Fig. 2), microbial growth might be impaired by a lack of nitrogen $[32,45,50]$. This might be of particular importance for maize silage diets, which have been suggested to induce a considerable lag time for maximal microbial growth [59]. However, other researchers have suggested the ability of rumen bacteria to incorporate $\mathrm{NH}_{3}-\mathrm{N}$ to a 15 fold gradient [48] through which their growth would not be impaired at lower $\mathrm{NH}_{3}-\mathrm{N}$ concentrations ([46], J.R. Wallace, 2000, personal communication).

\subsection{Rumen microbial growth}

Topps and Elliott [57] were the first researchers to link the total renal excretion of purine derivatives to the quantity of microbial biomass produced in the rumen. This relation has been confirmed extensively afterwards (e.g. review by Shingfield [51]). Moreover, blood allantoin concentrations in cattle have been correlated with renal excretion of purine derivatives [11, 24, 47] and rumen microbial growth [55]. Hence, in our experiments, the effect of dietary treatment on duodenal microbial $\mathrm{N}$ supply has been evaluated from the renal excretion of purine derivatives (Exps. 2 and 3) or blood allantoin concentrations (Exp. 1).

Both blood allantoin concentrations (Tab. V) and renal excretion of purine derivatives (Tab. VI), suggest that N supplementation to maize silage diets did not improve rumen microbial growth yield. In this way, addition of RDN to maize silage diets, fed at maintenance, only resulted in an increased environmental pollution as urinary urea-N excretion increased significantly (Tab. VI). However, blood allantoin concentrations (Exp. 1, Tab. V) and urinary purine metabolite excretion (Exps. 2 and 3, Tab. VI) were rather low compared to values reported in the literature for lactating cows $(370.6 \pm$ $\left.79.1 \mu \mathrm{mol} \cdot \mathrm{L}^{-1},[47]\right)$ or ovines $(12.2 \pm$ $\left.3.5 \mathrm{mmol} \cdot \mathrm{d}^{-1},[51]\right)$. Due to the assumptions made, Chen and Gomes [12] stressed predictions of microbial nitrogen supply from urinary excretion of purine derivatives $\left(\mathrm{MN}_{\mathrm{PD}}\right)$ should not be taken as absolute measurements. Still, $\mathrm{MN}_{\mathrm{PD}}$, ranging from 4.3 to $6.1 \mathrm{~g} \mathrm{~N} \cdot \mathrm{d}^{-1}$ for the sheep of experiments 2 and 3 , indicated that the microbial nitrogen supply was significantly lower than predicted from the Belgian and Dutch protein evaluation system $\left(\mathrm{MN}_{\mathrm{FOM}}\right.$,

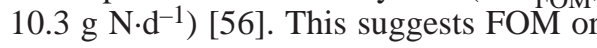


Table VI. Rumen RNA concentrations (mg per $100 \mathrm{~g}$ fresh rumen contents) $16 \mathrm{~h}$ after feeding (mean, $n=24)$ and daily renal excretion of urea-N $\left(\mathrm{g} \cdot \mathrm{d}^{-1}\right)($ mean, $n=12)$ and purine derivatives $\left(\mathrm{mmol} \cdot \mathrm{d}^{-1}\right)($ mean, $n=12)$ of experiments 2 and 3 .

\begin{tabular}{|c|c|c|c|c|c|c|c|c|c|c|c|}
\hline & \multicolumn{6}{|c|}{ Experiment 2} & \multicolumn{5}{|c|}{ Experiment 3} \\
\hline & \multirow[t]{2}{*}{ Blank } & \multirow[t]{2}{*}{ Urea } & \multirow[t]{2}{*}{ CRNPN $^{1}$} & \multirow[t]{2}{*}{ S.E.M. ${ }^{2}$} & \multicolumn{2}{|c|}{ Statistics $^{3}$} & \multirow[t]{2}{*}{ Blank } & \multirow[t]{2}{*}{ Protein } & \multirow[t]{2}{*}{ S.E.M. ${ }^{2}$} & \multicolumn{2}{|c|}{ Statistics $^{3}$} \\
\hline & & & & & Animal & N suppl. & & & & Animal & $\mathrm{N}$ suppl. \\
\hline RNA & $89.4^{\mathrm{a}}$ & $151.8^{\mathrm{b}}$ & $152.9^{\mathrm{b}}$ & 2.9 & $* * *$ & $*$ & 83.2 & 135.2 & 4.0 & $* * *$ & 0.101 \\
\hline Urea-N & $3.19^{\mathrm{a}}$ & $8.03^{b}$ & $8.05^{\mathrm{b}}$ & 0.46 & 0.234 & $* * *$ & 2.58 & 7.10 & 0.24 & 0.114 & $* * * *$ \\
\hline Purine & 6.35 & 6.58 & 6.77 & 0.54 & 0.251 & 0.892 & 5.64 & 6.61 & 0.32 & 0.226 & 0.074 \\
\hline
\end{tabular}

${ }^{1} \mathrm{CRNPN}$, controlled release non protein nitrogen (Quartes N.V., Deinze, Belgium).

${ }^{2}$ Standard error of mean.

$3 * * * p<0.001 ; * * p<0.01 ; * p<0.05$; when not significant, $p$-value is shown

a,b,c Different letters within same row indicate significant differences between different $\mathrm{N}$ supplements of experiment $2(p<0.05)$. 
microbial growth efficiency are significantly lower in our experiments than assumed by this protein evaluation system. Basically, the DVE/OEB system was developed for high yielding dairy cattle fed diets rich in RDN [56]. As a consequence, it might not be surprising that this system does not give accurate information for animals at maintenance, with lower rumen passage rates, or for diets deficient in RDN (e.g. maize silage). Indeed, both maize silage diets [20, $23,24,58]$ and slow rumen outflow rates [17] were reported to show reduced microbial growth efficiencies. Moreover, calculated $\mathrm{MN}_{\mathrm{PD}}$ values are slightly lower than microbial protein supply estimated from RDN of non supplemented maize silage diets $\left(\mathrm{MN}_{\mathrm{RDN}}, 6.8 \mathrm{~g} \mathrm{~N} \cdot \mathrm{d}^{-1}\right)$. This suggests no considerable compensation of presumed deficient RDN by urea recycling, probably because $\mathrm{N}$ supply from maize silage did not limit microbial growth in the rumen of animals at maintenance. It should be stressed, however, that some rumen $\mathrm{N}$ shortage might occur with time after feeding, as suggested from the rumen RNA concentrations (Tab. VI). Possibly the rumen RNA content, measured $16 \mathrm{~h}$ after feeding, is not representative for average rumen microbial RNA, determining renal purine derivative excretion, which might explain the discrepancy between the rumen RNA concentrations and renal excretion of purine derivatives.

\subsection{Effect of type of RDN}

Partial substitution of urea-N by a protein- $\mathrm{N}$ provoked a 50 to $95 \%$ increase in rumen microbial growth, at least at high levels of maize silage intake [14, 23]. It is unclear whether the latter is linked to a more synchronised energy and nitrogen supply for the rumen microbes [52], an increased need for degradable $\alpha$-amino acid-N to maximise microbial growth yield when feeding NPN sources [37] or a significant need for amino acids and peptides by amylolytic bacteria [49], which are more abundantly present with maize silage diets [42]. In order to exclude possible confounding between synchronisation and feed characteristics, we tried to evaluate the effect of the synchronisation rate, on the microbial growth yield using a CRNPN source. However, due to the poor slow release effect of the latter (Figs. 1 and 2), our objective failed. From the literature, however, synchronisation of $\mathrm{N}$ and energy supply has been suggested to play only a minor role when energy release is gradual (such as in maize silage) [3, 28]. Indeed, under such conditions, the plasma urea pool can be used as a 'N pool reserve', recycled to the rumen during periods of $\mathrm{N}$ shortage and considerable OM fermentation [35]. This was confirmed during an in vivo trial [41], in which the supplementation of a slow or fast protein-N source to maize silage did not induce a difference in microbial growth yield. On the contrary, Chamberlain and Choung [9] expected beneficial effects of synchronisation when the rumen $\mathrm{pH}$ is above 6.8 for significant periods of the feeding cycle, since $\mathrm{NH}_{3}$ absorption can be extensive. In our second and third experiment, $\mathrm{pH}$-values between 6.6 and 7.0 were achieved $7 \mathrm{~h}$ after feeding. Nevertheless, since no increase in microbial growth yield has been observed when supplementing the protein-N source, which induced a more gradual $\mathrm{NH}_{3}-\mathrm{N}$ release (Fig. 2), there is no convincing evidence that a closer synchronisation might ensure higher microbial protein synthesis under our experimental conditions. Furthermore, in contrast with the study of Cottrill et al. [14] who acknowledged the importance of the origin of the RDN source for microbial growth in trials with maize silage, replacement of the NPN sources by a protein-N source (Exp. 2 vs. Exp. 3) did not affect microbial growth yield in our experiment. It should, however, be recognised that urea$\mathrm{N}$ supply in the study of Cottrill et al. [14] represented up to $40 \%$ of the total $\mathrm{N}$ supply, where as in our experiment, this contribution was only $24.7 \%$ at the maximum 
(urea supplemented diet). Former experiments have revealed the origin of the $\mathrm{N}$ source to be only of minor $[7,10,46]$ or no [8] importance when urea represents less than $30 \%$ of the total N. Observed iso-acid proportions for the non supplemented, NPN and protein-N supplemented diets were similar to those reported by Peyraud et al. [46] However, as for the experiment of Peyraud et al. [46], the slight increase of iso-acids in the protein-N supplemented diet, did not improve microbial growth yield.

\section{CONCLUSION}

Irrespective of its origin, supplementation of RDN to maize silage diets, fed according to maintenance requirements, does not increase rumen microbial growth yield. As a consequence, application of the Belgian and Dutch protein evaluation system for animals at maintenance, fed maize supplemented diets, will overestimate the supply of true digestible protein in the small intestine (DVE) and underestimate renal $\mathrm{N}$ losses to the environment. Hence, for animals at lower production levels, estimations of OEB and DVE should be revised, in order to allow sparing of feeds and reducing environmental risks. Of course, the tolerance to reduced RDN supply for longer periods and the effect of deficient RDN on energy supply and animal response should be taken into account and need further long term research.

\section{REFERENCES}

[1] Balcells J., Guada J.A., Peiro J.M., Simultaneous determination of allantoin and oxypurines in biological fluids by high-performance liquid chromatography, J. Chromatogr. 575 (1992) 153-157.

[2] Beever D.E., Cottrill B.R., Protein systems for feeding ruminant livestock: a European Assessment, J. Dairy Sci. 77 (1994) 2031-2043.

[3] Blank R., Südekum K.H., Immig I., Kleinmans J., Synchroner Abbau von Kohlenhydraten und Rohprotein in den Vormägen - Eine neue Variable für die Rationsgestaltung?, Übers. Tierernährg. 26 (1998) 157-188.
[4] Burroughs W.N., Frank A., Gerlaugh P., Bethke R.M., Preliminary observations upon factors influencing cellulose digestion by rumen microorganisms, J. Nutr. 40 (1950) 9-24.

[5] Carlsson J., Pehrson B., The influence of the dietary balance between energy and protein on milk urea concentration. Experimental trials assessed by two different protein evaluation systems, Acta Vet. Scand. 35 (1994) 193-205.

[6] Castro F.B., Ørskov E.R., Selmer-Olsen I., Johnsen F., Improved properties of a novel controlled release feed grade urea, S. Afr. J. Anim. Sci. 29 (1999) 161-162.

[7] Cecava M.J., Parker J.E., Intestinal supply of amino acids in steers fed ruminally degradable and undegradable crude protein sources alone and in combination, J. Anim. Sci. 71 (1993) 1596-1605.

[8] Cecava M.J., Merchen N.R., Berger L.L., Fahey G.C. Jr., Effects of dietary energy level and protein source on site of digestion and duodenal nitrogen and amino acid flows in steers, J. Anim. Sci. 66 (1988) 961-974.

[9] Chamberlain D.G., Choung J.J., The importance of rate of ruminal fermentation of energy sources in diets for dairy cows, in: Garnsworthy P.C. Cole D.J.A. (Eds.), Recent advances in animal nutrition, Nothingham University Press, Nothingham, 1995, pp. 3-27.

[10] Chen X.B., Chen Y.K., Franklin M.F., Ørskov E.R., Shand W.J., The effect of feed intake and body weight on purine derivative excretion and microbial protein supply in sheep, J. Anim. Sci. 70 (1992) 1534-1542.

[11] Chen X.B., Fujihara T., Nakamura K., Mawuenyegah P.O., Franklin M.R., Kyle D.J., Response of urinary and plasma purine derivatives to various rates and infusion patterns of purines in sheep nourished by intragastric infusion, J. Agric. Sci. 129 (1997) 343-352.

[12] Chen X.B., Gomes M.J., Estimation of microbial protein supply to sheep and cattle based on urinary excretion of purine derivatives - an overview of the technical details, Occasional publication 1992, International Feed Resources Unit, Rowett Research Institute, Aberdeen (UK), 1995. http://www.mluri.sari.ac.uk/IFRU/ chema.pdf.

[13] Conway E.J., Microdiffusion analysis and volumetric error, Crosby, Lockwood and Son, Ltd, London, 1957.

[14] Cottrill B.R., Beever D.E., Austin A.R., Osbourn D.F., The effect of protein- and non-proteinnitrogen supplements to maize silage on total amino acid supply in young cattle, Brit. J. Nutr. 48 (1982) 527-541.

[15] CVB, Voedernormen voor rundvee, Centraal Veevoederbureau, Lelystad, 1995.

[16] Demeyer D., Quantitative aspects of microbial metabolism in the rumen and hindgut, in Jouany J.P. (Ed.), Rumen microbial metabolism and ruminal digestion, INRA, Paris, 1991 pp. 217-237. 
[17] Demeyer D., Van Nevel C., Influence of substrate and microbial interaction on efficiency of rumen microbial growth, Reprod. Nutr. Dev. 26 (1986) 161-179.

[18] Dierick N., Studie van de invloed van de darmflora en van enkele groeibevorderende voederadditiva op het stikstofmetabolisme bij het varken, Ph.D. thesis in Agricultural Sciences, Ghent University, 1985.

[19] Diez M., Hornick J.L., Baldwin P., van Eenaeme C., Istasse L., The influence of sugar-beet fibre, guar gum and inulin on nutrient digestibility, water consumption and plasma metabolites in healthy Beagle dogs, Res. Vet. Sci. 64 (1998) 91-96.

[20] Dijkstra J., France J., Comparison of protein evaluation models for ruminants, S. Afr. J. Anim. Sci. 29 (1999) 162-163.

[21] Dijkstra J., France J., Davies D.R., Different mathematical approaches to estimating microbial protein supply in ruminants, J. Dairy Sci. 81 (1998) 3370-3384.

[22] Fievez V., De Fauw K., Notteboom K., Demeyer D., Validation of the degraded protein balance to predict efficiency of rumen $\mathrm{N}$-utilisation, Reprod. Nutr. Dev. 40 (2000) 203-204.

[23] Firkins J.L., Weis W.P., Piwonka E.J., Quantification of intraruminal recycling of microbia nitrogen using nitrogen-15, J. Anim. Sci. 70 (1992) 3223-3233.

[24] Giesecke D, Balsliemke J., Südekum K.H., Stangassinger M., Plasmaspiegel, clearance sowie renale Ausscheiding von endogenen und ruminalen Purinen beim Rind, Anim. Physiol. a. Anim. Nutr. 70 (1993) 180-189.

[25] Gonda H.L., Lindberg J.E., Evaluation of dietary nitrogen utilization in dairy cows based on urea concentrations in blood, urine and milk, and urinary concentration of purine derivatives, Acta Agric. Scand. 44 (1994) 236-245.

[26] Gonda H.L., Emmanuelson M., Murphy M., The effect of roughage to concentrate ratio in the diet on nitrogen and purine metabolism in dairy cows, Anim. Feed Sci. Technol. 64 (1996) 27-42.

[27] Gustafsson A.H., Palmquist D.L., Diurnal variation of rumen ammonia, serum urea, and milk urea in dairy cows at high and low yields, J. Dairy Sci. 76 (1993) 475-484.

[28] Henning P.H., Stey D.G., Meissner H.H., Effect of synchronization of energy and nitrogen supply on ruminal characteristics and microbial growth, J. Anim. Sci. 71 (1993) 2516-2528.

[29] Herbert D., Phipps P.J., Strange R.E., Determination of RNA by the orcinol method, in: Norris J.R., Ribbons D.W. (Eds.), Methods in microbiology, Volume 5b, Academic Press Inc., London, 1971, pp. 316-320.
[30] Herrera-Saldana R., Gomez-Alarcon R., Torabi M., Huber J.T., Influence of synchronizing protein and starch degradation in the rumen on nutrient utilization and microbial protein synthesis, J. Dairy Sci. 73 (1990) 142-148.

[31] Hoover W.H., Stokes S.R., Balancing carbohydrates and proteins for optimal rumen microbial yield, J. Dairy Sci. 74 (1991) 3630-3644.

[32] Hume I.D., Miror R.J., Somers M., Synthesis of microbial protein in the rumen. 1. Influence of the level of nitrogen intake, Aust. J. Agric. Res. 21 (1970), 283-296.

[33] Jouany J.P., Demeyer D., Grain J., Effect of defaunating the rumen, Anim. Feed Sci. Technol. 21 (1988) 229-265.

[34] Kayouli C., Van Nevel C.J., Dendooven R., Demeyer D., Effect of defaunation and refaunation of the rumen on rumen fermentation and $\mathrm{N}$-flow in the duodenum of sheep, Arch. Anim. Nutr. 36 (1986) 827-837.

[35] Kennedy P.M., Milligan L.P., The degradation and utilization of endogenous urea in the gastrointestinal tract of ruminants: a review, Can J. Agric. Sci. 60 (1980) 205-211.

[36] Kim K.H., Choung J.J., Chamberlain D.G., Effects of varying the degree of synchrony of energy and nitrogen release in the rumen on the synthesis of microbial protein in lactating dairy cows consuming a diet of grass silage and a cereal-based concentrate, J. Sci. Food Agric. 79 (1999) 1441-1447.

[37] Maeng W.J., Baldwin R.L., Factors influencing rumen microbial growth rates and yields: effect of amino acid additions to a purified diet with nitrogen from urea, J. Dairy Sci. 59 (1976) 648-655.

[38] Marty R., Demeyer D., The effect of inhibitors on methane production, on fermentation pattern and stoichiometry in vitro using contents of sheep given molasses, Brit. J. Nutr. 30 (1973) 369-376.

[39] Mbanzamihigo L., Vandycke E., Demeyer D.I., Degradation of methionine by rumen contents in vitro and efficiency of its protection, Anim. Feed Sci. Technol. 67 (1997) 339-347.

[40] McAllan A.B., Smith R.H., Nucleic acid metabolism in the ruminant, Brit. J. Nutr. 23 (1969) 671-682.

[41] McCarthy R.D. Jr., Klusmeyer T.H., Vicini J.L., Clark J.H., Nelson D.R., Effects of source of protein and carbohydrate on ruminal fermentation and passage of nutrients to the small intestine of lactating cows, J. Dairy Sci. 72 (1989) 2002-2016.

[42] Neal H.D.St.C., Dijkstra J., Gill M., Simulation of nutrient digestion, absorption and outflow in the rumen: model evaluation, J. Nutr. 122 (1992) $2257-2272$ 
[43] Nocek J.E., Russell J.B., Protein and energy as an integrated system. Relationship of rumina protein and carbohydrate availability on microbial synthesis and milk production, J. Dairy Sci. 71 (1988) 2070-2107.

[44] Oltner R., Wiktorsson H., Urea concentration in milk and blood as influenced by feeding varying amounts of protein and energy to dairy cows, Livest. Prod. Sci. 10 (1983) 457-467.

[45] Orkie A.U., Buttery P.J., Lewis D., Ammonia concentration and protein synthesis in the rumen, Proc. Nutr. Soc. 36 (1977) 38-49.

[46] Peyraud J.L., Le Liboux S., Vérité R., Effet du niveau et de la nature de l'azote dégradable su la digestion ruminale d'un régime à base d'ensilage de maïs chez la vache laitière, Reprod. Nutr. Dev. 37 (1997) 313-328.

[47] Rosskopf R., Rainer H., Giesecke D., Purinund Pyrimidinmetaboliten zur Beurteilung des Pansenstoffwechsels: HPLC-Analysen in Milch und Blutplasma, Arch. Anim. Nutr. 41 (1991) 411-426.

[48] Russell J.B., Strobel J.H., Concentration of ammonia across cell membranes of mixed rumen bacteria, J. Dairy Sci. 70 (1987) 970-976.

[49] Russell J.B., O’Connor J.D., Fox D.G., Van Soest P.J., Sniffen C.J., A net carbohydrate and protein system for evaluating cattle diets: I. Ruminal fermentation, J. Anim. Sci. 70 (1992) 3551-3561

[50] Satter L.D., Slyter L.L., Effect of ammonia concentration on rumen microbial protein production in vitro, Brit. J. Nutr. 32 (1974) 199-208.

[51] Shingfield K.J., Estimation of microbial protein supply in ruminant animals based on rena and mammary purine metabolite excretion. A review, J. Anim. Food Sci. 9 (2000) 169-212.

[52] Sinclair L.A., Garnsworthy P.C., Newbold J.R. Buttery P.J., Effect of synchronizing the rate of dietary energy and nitrogen release on rumen fermentation and microbial protein synthesis in sheep, J. Agric. Sci. 120 (1993) 251-263.
[53] Sinclair L.A., Garnsworthy P.C., Newbold J.R., Buttery P.J., Effects of synchronizing the rate of dietary energy and nitrogen release in diets with a similar carbohydrate composition on rumen fermentation and microbial protein synthesis in sheep, J. Agric. Sci. 124 (1995) 463-472.

[54] Sniffen C.J., O’Connor J.D., Van Soest P.J, Fox D.G., Russell J.B., A net carbohydrate and protein system for evaluating cattle diets: II. Carbohydrate and protein availability, J. Anim. Sci. 70 (1992) 3562-3577.

[55] Stangassinger M., Chen X.B. Lindberg J.E. Giesecke D., Metabolism of purines in relation to microbial production, in: Engelhardt W.V. Leonhard-Marek S., Breves G., Giesecke D. (Eds.), Ruminant Physiology: digestion, metabolism, growth and reproduction. Proceedings of the eight international symposium on ruminant physiology, Ferdinand Enke Verlag, Stuttgart, 1995, pp. 387-406.

[56] Tamminga S., Van Straalen W.M., Subnel A.P.J., Meijer R.G.M., Steg A., Wever C.J.G., Blok M.C., The Dutch protein evaluation system: the DVE/OEB-system, Livest. Prod. Sci. 40 (1994) 139-155.

[57] Topps J.H., Elliot R.C. Relationship between concentrations of ruminal nucleic acids and excretion of purine derivatives by sheep, Nature 205 (1965) 498-499.

[58] Vagnoni D.B., Broderick G.A., Clayton M.K., Hatfield R.D., Excretion of purine derivatives by Holstein cows abomasally infused with incremental amounts of purines, J. Dairy Sci. 80 (1997) 1695-1702.

[59] Van Gelder A.H., Cone J.W., Het meten van verschillen in microbiële groei met de gasproductietechniek, Proceedings 23th Studiedag Nederlandstalige Voedingsonderzoekers, Utrecht, 1998, pp. 21-22 (in Dutch).

[60] Vérité R., Michalet-Doreau B., Chapoutot P., Peyraud J.L., Poncet C., Révision du système de protéines digestibles dans l'intestin (PDI), Bull. Tech. CRZV Theix, INRA 70 (1987) $19-34$. 